Reprod. Nutr. Dévelop., 1988, 28 (2 B), 443-458.

\title{
The role of the pineal gland in the photoperiodic control of reproduction in different hamster species
}

\author{
P. PÉVET
}

Laboratoire de Zoologie et d'Embryologie expérimentale, J.E. CNRS 033669,

Université L. Pasteur, 12, rue de I'Université, 67000 Strasbourg. France.

Summary. The pineal gland is known to play a central role in the photoperiodic control of reproduction in seasonal breeders. The present review, based on experimental data obtained in four different species of hamster, the Syrian or golden, the Djungarian or Siberian, the Turkish and the European, attempts to evaluate the role of the pineal in this phenomenon, the message which is conveyed from this gland as well as the mechanism of action of this message.

Melatonin one of the 5-methoxyindoles rhythmically synthesized in the pineal gland, appears to be the pineal hormone conveying the photoperiodic message. The importance of the duration of the nocturnal peak of circulating melatonin is now well established, but our knowledge on the sites of action and on the mechanisms of action of melatonin is still rather poor. The presently available data suggest that melatonin can act at different levels, either on specific receptors, on receptors of other transmitters, on various molecular processes after diffusion in the cell or indirectly via effects on other endocrine hormones, e.g. gonadal steroids.

\section{Introduction.}

Many mammalian species are able to respond to annual changes in daylength by adaptative alterations in physiological as well as in behavioural states in anticipation of the coming season. The switching on and off of the reproductive function during the annual breeding cycle is the most striking example of such a photoperiodically induced process.

Although the relationship between photoperiodic changes and the sexual cycle of mammals has since long been recognized (Bissonette 1932, Baker and Ranson, 1932), there are only 2 decades that the pineal gland has been demonstrated to have a key function in this adaptative mechanism.

In 1964 Czyba et al. and in 1965 Hoffman and Reiter observed that in the golden hamster pinealectomy prevented the gonadal regression normally brought about by blinding or by experimental or natural short photoperiod. From this time on this result has been confirmed and developed, the golden hamster being by far the most commonly used experimental animal in pineal research (for review see Reiter, 1980). It is however the comparative analysis of these results with those 
obtained in other species, especially hamster ones, which have permitted to understand the exact role of the pineal : to convey photoperiodic informations upon the neuroendocrine axis (for review see Goldman, 1983 ; Hoffmann, 1985).

Although the role of the pineal is well established in general, it appears to date that this gland is only part of a very complex system of neural and neuroendocrine control mechanisms responsible for the photoperiodic response and that its mechanism of action is still not yet fully understood.

The present mini-review, based on experimental data obtained in four different hamster species, the golden or Syrian (Mesocricetus auratus), the Djungarian or Siberian (Phodopus sungorus), the Turkish (Mesocricetus brandti) and the European (Cricetus cricetus), is an attempt to evaluate the role of the pineal, the message which is conveyed by this gland as well as its mechanisms of action.

\section{Photoperiod, pineal and reproduction}

In the golden hamster, the influence of the photoperiod and of the pineal gland on reproduction is now well documented. We will therefore use this species as reference and examine the differences observed from this central scheme in other hamster species.

The gonadal activity of the golden (or Syrian) hamster is directly dependent on the photoperiodic regime showing a marked "critical photoperiod " to be defined, in animals coming from long photoperiod (LP), as the minimal duration of light per day necessary for gonadal activity. This critical photoperiod is of 12 h 30 min light per day (Elliot, 1976). Daily light shorter than 12 h 30 min - either complete darkness or $12 \mathrm{~h}$ light - is interpreted by the animals as a short photoperiod (SP) which causes regression of their reproductive organs within approximately 8 weeks, at least under classical laboratory conditions (Pévet et al., 1986a,b ; Li et al., 1987). Spermatogenesis is completely suppressed in males, while in females a cessation of ovulation and of the estrous cycle and a regression of the uterus is observed (for details and references see Reiter, 1980, 1987a ; Stetson and Watson-Whitmyre, 1984). Such an inhibitory effect of SP is also observed at the hormonal level. In the male a clear decrease of the circulating levels of testosterone, $\mathrm{LH}, \mathrm{FSH}$ and prolactin and of the pituitary content of these last three hormones is noted, prolactin exhibiting the most pronounced and consistent changes. In the female, however, the situation is more complex. An increase of $\mathrm{FSH}$ and $\mathrm{LH}$ concentration in the pituitary as well as in the plasma is noted. This observation is not clearly understood (for details and references see Reiter, 1980 ; Hoffmann, 1981a). As already noted in the introduction, the pineal gland is since 1964 known to be directly implicated in this phenomenon. Indeed, if after pinealectomy no change is observed in golden hamsters kept under long photoperiod (LP), this operation prevents completely the gonadal atrophy induced by SP. Changes in gonadotropin and prolactin levels associated with the gonadal response to SP are also completely abolished after pinealectomy (for review see Reiter, 1980 ; Hoffmann, 1981a). After 20-25 weeks exposure to SP hamsters show a spontaneous regrowth of the gonads, but 
before this time and throughout these 20-25 weeks pinealectomy induces premature recrudescence of the gonads (Reiter, 1969). When spontaneous regrowth has occurred, the animals are said to be photorefractory because they do not respond anymore to continued exposure to SP. This photorefractory state can be broken by exposure to LP for 10-15 weeks. Following such treatment the hamsters respond again to SP. Subsequent studies performed on hamsters kept under natural photoperiodic and temperature conditions throughout the year demonstrated that the animals were sexually active during spring and summer (LP) and inactive during the short days of the winter. Field studies are lacking - all Syrian hamsters used in the different laboratories being obtained from highly domesticated colonies (see Murphy, 1985) - but in laboratory investigations under both natural and artificial photoperiodic conditions Reiter (1973-1975) determined the exact relationships between photoperiod, pineal and annual sexual cycle. The golden hamster is a long-day breeder. This means that it reproduces in spring and summer when daylength is long (e.g. $>12 \mathrm{~h} 30 \mathrm{~min}$ ). At the beginning of September, when daylength falls below $12 \mathrm{~h} 30$ min, gonadal atrophy occurs. Near the end of the winter, even though the daylength is still short (i.e. $<12 \mathrm{~h} 30 \mathrm{~min}$ ), refractoriness develops and the neuroendocrine reproductive axis is reactivated preparing the golden hamster for breeding in the early spring. Then the long days of the spring and summer serve to break the refractory period allowing a gonadal regression to occur in the following autumn. To generate the annual reproductive cycle described, the golden hamster must thus "measure " long and short daylengths. For this the pineal is necessary. When pinealectomized $(\mathrm{Px})$ in August, golden hamsters kept under natural conditions do not present the gonadal atrophy which normally occurs in September-October remaining continuously sexually active regardless of the season of the year or of the prevailing photoperiod (see Reiter, 1973, 1980).

When kept under natural environmental conditions the Djungarian hamster (Phodopus sungorus) also shows a marked annual sexual cycle similar to that described in the golden hamster (Hoffmann, 1973). All experiments conducted to study in adults of this species the influence of the photoperiod on reproductive activity and the role of the pineal in this phenomenon gave approximately the same results as in the golden hamster. After exposure to SP the gonads of the Djungarian hamster completely regress within 8-10 weeks, an endogenous recrudescence being observed after 20-25 weeks. If the animals are pinealectomized prior to SP exposure, gonadal regression does not occur. However, and contrary to what was observed in the golden hamster, pinealectomy performed after gonadal regression had been induced by exposure to SP, prevents the gonadal regrowth normally obtained by subsequent transfer to LP (for details and references see Hoffmann, 1979, 1981a,b, 1985 ; Stetson and Watson-Whitmyre, 1986 ; Goldman, 1983).

The critical photoperiod in the Djungarian hamster is of approximately the same duration as in the golden hamster (13 h versus $12 \mathrm{~h} 30$ (Hoffmann, 1982). However, contrary to the golden hamster where the critical photoperiod is independent of the previous light regime, the critical photoperiod in the Djungarian hamster appears to be dependent on the photoperiodic regime in 
which the animals have been raised before the experiment. Hoffmann (1981b), for example, found that a diurnal cycle of 14L : 10D can be interpreted as either LP - stimulatory to reproduction - or as SP -inhibitory to reproductiondepending on whether the animals had previously been kept in SP or LP.

A further difference between these two species is that in golden hamsters photoperiod sensibility begins only after puberty, while in the Djungarian hamster sexual development is largely dependent on daylength. When maintained from birth on in LP, these hamsters have large and functional testes at the age of 40 days while in SP testicular development is delayed up to about 180 days of age. Under these conditions pinealectomy prevents the SP-induced inhibition of sexual maturation.

As with the golden or Djungarian hamster, exposure of adult male Turkish hamsters to SP (10L : 14D) induces within 8-10 weeks a regression of the gonadal axis which is followed after 20-25 weeks by a spontaneous regrowth (photorefractory period) (Carter et al., 1982). Exposure to long days is necessary to break off this photorefractory period (Hong and Stetson, unpublished data cited in Stetson and Watson-Whithmyre, 1986). Contrary to what was mentioned for the golden and Djungarian hamster, in the Turkish hamster, pinealectomy fails to prevent the short-photoperiodically (SP) induced gonadal atrophy. In contrast, removal of the pineal induces gonadal atrophy in adult male Turkish hamsters kept under LP (16L : 8D) (Carter et al., 1982). Interestingly, the gonadal axis of pinealectomized hamsters is then reactivated after 20-24 weeks, and becomes functional (Carter et al., 1982). In adult Syrian and Djungarian hamsters, the critical photoperiod was defined as the minimal daylength necessary for gonadal activity. In the Turkish hamster this phenomenon appears to be more complex, a lower and upper critical photoperiod being present. The gonads showed activity when the animals were kept under photoperiodic regimes between 15 and $17 \mathrm{~h}$ of light/day. Any photoperiod above $17 \mathrm{~h}$ of light/day or below $15 \mathrm{~h}$ light/day induced gonadal atrophy (Hong et al., 1986) a fact which had never been described in any other photoperiodic species.

Like in the Djungarian hamster, the gonadal development in the Turkish hamster - both in male and female - is under photoperiodic control. Exposure to SP delays growth of the gonads in prepubertal animals (Stetson and WatsonWhitmyre, 1984).

Under natural conditions of light, temperature and humidity, the European hamster undergoes a very marked regression in testis size as well as in circulating testosterone levels in August and stays in sexual quiescence till April (Canguilhem et al., 1986). Like in other hamster species, the sexual cycle is apparently regulated by the photoperiod. The decline in sexual activity observed under natural conditions from August to March is mostly absent when the animals are kept under LP (16L : 8D) (Masson-Pévet et al., 1987 ; Canguilhem et al., 1988). Evidently, LP has a stimulating effect on the gonadal axis at least maintaining this axis in an active phase (Masson-Pévet et al., 1987 ; Canguilhem et al., 1988). Experimentally it has also been observed that 8 weeks of exposure to SP induces a complete gonadal and accessory sex organ atrophy (Masson-Pévet et al., 1987). The latter observation suggests that the decline in sexual activity observed under 
natural conditions in August is due to the decrease of daylength at this period of the year. This conclusion is supported by an observation of Canguilhem et al., (1988). These authors, experimentally studying the photoperiodic regulation of body weight in this hamster, found the critical photoperiod to be comprised between $15-15 \mathrm{~h} 30 \mathrm{~min}$, a value which corresponds to the daylength in Strasbourg at the beginning of August.

European hamsters catched at the end of the hibernation period and kept immediately and continuously under a short photoperiodic regime (8L: 16D) remain apparently continuously sexually active (Canguilhem et al., 1988). However, sexually active animals which were kept under SP since their capture and then exposed to LP for 20 weeks responded again to a short photoperiodic regime by gonadal atrophy (Canguilhem et al., 1988). These results clearly establish that the European hamster when catched in spring at the end of the hibernation period is in a photorefractory state.

Thus it appears that during the year the European, like the other hamster species studied, presents two different and opposite types of sensibility to photoperiod which explain the annual course of sexual activity. Gonadal regression is observed in August when daylength decreases and falls below the critical photoperiod (15-15 h 30). Gonadal activity spontaneously reactivates in March-April when the animals still hibernate in the dark in their burrow. In autumn and the beginning of winter the animals are photosensitive, while at the end of the winter and the beginning of spring, recrudescence of the gonads is endogenous, the animal being in a photorefractory state. Reinitiation of the photosensitive state occurs at the end of spring and in summer by exposure to LP. As experimentally demonstrated by Canguilhem et al. (1988) this exposure to long photoperiod abolished the refractory state. In consequence the animals present again a sexual involution in response to the decreasing daylength in summer or to an experimental short photoperiod.

The pineal gland is implicated in the photoperiodic regulation of the sexual cycle being apparently involved in the gonadal maintenance induced by exposure to LP. Like in the Turkish hamster and contrary to the Syrian or Djungarian hamster, removal of the pineal in the European hamster has no effect on the gonadal atrophy induced by SP, inducing on the contrary a testicular regression in animals kept under LP (Masson-Pévet et al., 1987).

From the data reported above it appears that the gonadal response to pinealectomy is different from one species of hamster to another. There is, however, a common feature in these varied responses. In each species pinealectomy prevents the perception of a change in the photoperiod, the difference observed at the gonadal level being due to differences in the reaction of the animals to the non-perception of photoperiodic information. Evidently the role of the pineal is to convey the photoperiodic message to the neuroendocrine axis (for more details see Hoffmann 1981a, 1985 ; Goldmann 1983).

\section{The role of melatonin in the photoperiodic control of reproduction.}

The biosynthetic/secretory activity of the pineal gland is regulated by the light/dark cycle and by an endogenous circadian oscillator. The regulatory 
influences are conveyed to the pineal via its innervation from the superior cervical ganglia and ultimately result in a day/night rhythm synthesis of pineal factors such as for example serotonin (Steinlechner et al., 1983 ; Quay, 1963), 5methoxytryptophol (Beck and Pévet, 1984 ; Skene et al., 1987 ; Mefford et al., 1983), 5-methoxytryptamine (Galzin et al., 1988) and melatonin (for references see Reiter, 1980). The physiological properties of most of these putative pineal hormones are yet poorly defined but on one of them, melatonin, extensive studies have been performed and it is now generally accepted that this hormone is responsible for the mediation of the effects of the pineal.

In the past few years the endocrine effects of melatonin were initially defined in relationship to reproduction (see review in Reiter, 1980) and, considering hamster species, apparent contradictory results were obtained. For example, continuous release of melatonin can either suppress reproduction under long photoperiodic conditions (Turkish, European and Djungarian hamster : Carter et al., 1982 ; Hoffmann, 1973 ; Masson-Pévet et al., 1987), block gonadal regression under SP (Syrian and Djungarian hamsters, Reiter et al., 1977 ; Hoffmann, 1973) or have no effect under LP (Syrian hamster, Reiter et al., 1977). In general it appears that the results obtained with exogenously administered melatonin are dependent on the method of administration as well as of the reproductive status of the animals and on the prevailing photoperiod (for a complete review see Stetson and Watson-Whitmyre, 1986).

The concept that the pineal is not directly implicated in the control of reproductive function but that it mediates the effects of photoperiod on reproduction have imposed a reinterpretation of all earlier experimental data. In the present review we will specially deal with the melatonin as the chemical compound resulting from the transduction of photoperiodic informations in the pineal.

In all mammals studied to date, including 3 of the 4 hamster species considered (the Syrian, the Djungarian and the Turkish), pineal melatonin synthesis is increased during the night. So far as can be determined melatonin is not stored within the pineal gland in any appreciable quantity. Once synthetized it is released into the bloodstream. In consequence the blood level of melatonin follows that of the pineal gland. Thus the highest circulating levels of melatonin occur during the night. In all species investigated light at night suppresses the high values of melatonin normally observed at this time and the diurnal change in melatonin concentration in the pineal and in the blood is abolished by constant light.

These observations clearly suggest that the rhythmic melatonin secretion is necessary for the mediation of photoperiodic effects. In the Djungarian hamster it was quickly clearly established that the temporal pattern of pineal melatonin content reflects the length of the photoperiod. The length of time during which the melatonin level is elevated above the low daytime value changes with the length of the dark period (within some limits) (see Goldman, 1983; Hoffmann 1981a-1985). Contrary to what has been claimed for some time (Panke et al., 1980 ; Rollag et al., 1980 ; Tamarkin et al., 1980) this also appears to be true in the Syrian hamster (Roberts et al., 1985 ; Skene et al., 1987). Similar data were 
also obtained in the sheep (review in Arendt, 1986) and the white footed mouse (Petterborg et al., 1981).

These results strongly suggest that the duration of elevated melatonin levels might be the important factor in conveying photoperiodic information. This has been clearly established in the Djungarian hamster and confirmed in the sheep (see other articles in the present book). Carter and Goldman (1983a,b) and Goldman (1983) using a daily programmed subcutaneous infusion of melatonin, at doses that mimic " normal " nightime melatonin levels in pinealectomized young Djungarian hamster kept under LP, observed that $12 \mathrm{~h}$ daily infusion, but not 6 or $4 \mathrm{~h}$ blocks gonadal development as does SP. Daily melatonin infusions of long duration were effective in eliciting a short day response. Interestingly, the timing of the melatonin infusion relative to the light dark cycle was unimportant in determining the effect. Conversely, in young Djungarian hamsters kept under SP, a condition in which the testicular development remains inhibited until 35 days of age, infusions of melatonin for 4 or $6 \mathrm{~h}$ daily but not for 8 or $12 \mathrm{~h}$ stimulated testicular growth in 23 day-old pinealectomized hamsters, a result similar to that obtained by exposure to LP. Daily melatonin infusions of short duration were effective in eliciting a long day response.

Based on these data most scientists presently believe that the photoperiodic message is conveyed to the neuroendocrine axis via the rhythmic pattern of melatonin secretion. How melatonin acts at the cellular level and which are its sites of action remains however to be determined.

\section{Mechanism and sites of action of melatonin.}

As just explained, the duration of the nocturnal peak of circulating melatonin conveys photoperiodic information to the brain. Presently two hypotheses are used to explain such an action, the duration hypothesis and the coincidence hypothesis.

The duration hypothesis, proposed by Goldman (1983), derived directly from the experiments on the Djungarian hamster as exposed above. It is thus based on experimental data which are the more sound because they have been confirmed in another species, the sheep (see the present book). This hypothesis also explains results obtained in the past, for example the gonadal regression induced by late afternoon daily injections of melatonin in golden hamsters kept under LP. Under these conditions the administered melatonin summates with the endogenous melatonin peak, gonadal atrophy being the result of the prolongation of the nocturnal elevated melatonin obtained in this way.

The coincidence hypothesis has been proposed in 1983 by Reiter. Following this hypothesis, two rhythms are required, i.e. the melatonin rhythm and a rhythm of sensibility to melatonin. This hypothesis also explains why daily late afternoon melatonin injections induce gonadal atrophy. Melatonin administered in the afternoon is considered to shift the period of melatonin sensitivity into phase with the endogenous melatonin. 
Recently this hypothesis has been further elaborated and two models, the internal coincidence and the external coincidence ones, being proposed (Reiter, 1987b). This hypothesis is also attractive and might explain some results difficult to interpret with the duration hypothesis (for an extensive review see Reiter, $1987 a, b)$. It, however, needs strong experimental support to be validated. Presently and although both hypotheses are not mutually exclusive, most groups favour the duration hypotheses. Only progress in our knowledge on the exact sites of action of melatonin as well as on its mechanism of action will solve this debate.

Looking at the numerous photoperiod-dependent seasonal functions reported in the literature which need the pineal for expression, it is evident that we face a very complex problem. Melatonin, for example, could act 1) either at a single site in the brain which would then be implicated in the regulation of very different seasonal functions or 2) it could act at multiple sites, each of them controlling the timing of a given seasonal function. In case of multiple sites of action of melatonin some of them might be situated outside the central nervous system, e.g. in hair follicles, gonads or retina (Cohen et al., 1978; Weatherhead, 1981 ; Kano and Miyachi, 1976 ; Dubocovich, 1983).

At the target site itself, melatonin could also act at very different levels. Melatonin, for example, like all classical informative molecules could possibly act on a specific receptor site. It could, however, also act on other receptor sites to modulate their responses. Moreover, given its lipophilic nature, melatonin is able to cross membranes and a possible direct modulatory effect of this hormone on several physiological cell processes cannot be excluded.

\section{1. - Melatonin receptors.}

By using ${ }^{3} \mathrm{H}$-melatonin as a radioligand two laboratories published in 1978 , the first description of the occurrence of specific binding sites for melatonin. Cohen et al. (1978) observed melatonin cytosol binding sites in peripheral tissues of rat and hamster, e.g. ovary, uterus, testis and eyes, while Cardinali et al. (1979) found melatonin binding activities in the crude membrane fraction of the bovine medio-basal hypothalamus. Studies on binding affinities of melatonin analogues allowed the authors to conclude that the 5-methoxy- and N-acetylgroup were needed for full expression of the binding capacities. Other areas of the bovine and rat brain also exhibited melatonin binding activities. Among the various tissues examined the highest membrane melatonin receptor concentration was found in the rat hypothalamus and pituitary gland. Lang et al. (1981) confirmed these results detecting also binding sites for melatonin both in the cytosol and in the cell membranes, the greatest number of receptors being observed in the hypothalamus and the eye.

Probably because of the poor quality of the radioligand used at that time this type of work was not followed by the additional studies which would have permitted to fully characterized melatonin receptors.

Recently however new approaches to this problem and radioligands of better quality have brought some progress. Niles (1987), for example, described high 
affinity binding of ${ }^{3} \mathrm{H}$-melatonin especially in membrane and soluble fractions of calf and rat brains. Both fractions exhibited similar binding affinities, but the concentration of binding sites was significantly higher in brain membranes. Dubocovich $(1983,1985)$ demonstrated that melatonin is a potent inhibitor of the calcium-dependent release of dopamine from rabbit and chicken retinae and concluded to the presence, in the retina, of a melatonin binding site possessing the pharmacological characteristics of a receptor. Zisapel and Laudon (1982) observed that melatonin inhibits the stimulated release of dopamine from rat hypothalamus and concluded that melatonin receptors are present. Recently they used (Zisapel and Laudon, 1987) this system to test with success the potencies of putative melatonin antagonists. The same group (Laudon and Zisapel, 1985), using ${ }^{125} \mathrm{I}$-melatonin as a ligand also succeeded in characterizing central melatonin receptors and in determining their distribution within the brain of the female rat (hypothalamus, medulla-pons, hippocampus, cerebellum, striatum and parietal cortex). The number of receptors in the medulla-pons and in the hypothalamus was dependent on the level of circulating oestradiol (Laudon and Zisapel, 1987). Using autoradiography, Vanecek et al. (1987) were able to detect displacable ${ }^{125} \mid-$ melatonin binding sites in the suprachiasmatic nucleus and the median eminence. Further studies, performed on crude membrane preparations from the median eminence, revealed high affinity melatonin binding sites, the specificity being higher in comparison to that of all receptors previously described (Vanecek et al., 1987).

Much progress has been made in recent years on the problem of melatonin receptors and if additional work is performed to fully characterize these receptors and to determine their anatomical localization, it is evident that this will give important information on the mechanism of action of melatonin in the near future.

\section{2. - Melatonin action on other receptor sites.}

5-methoxytryptamine, one of the 5-methoxyindoles (including melatonin) synthesized in the pineal gland (Pévet, 1983 ; Galzin et al., 1988) is a very potent serotonin (5-HT) autoreceptor agonist inhibiting, in a concentration dependent manner, the electrically evoked release of ${ }^{3} \mathrm{H}-5-\mathrm{HT}$ from superfused rat hypothalamic slices (Galzin and Langer, 1986). This potent effect of 5methoxytryptamine on the serotoninergic neurotransmission, although not yet fully evaluated, is probably of physiological importance. It implicates that the possible existence of a similar mechanism for melatonin should be considered. For example it would be possible that the effect of melatonin on ${ }^{3} \mathrm{H}$-dopamine release from rabbit or chicken retina is not mediated via melatonin receptors as suggested by Dubocovich (1983, 1985 see above), but by the action of melatonin on dopamine receptors.

Considering the control of seasonal function, we do not have clear evidence of such a mechanism of action. It should, however, be remembered, that Smith and Kappers (1975) suggested that melatonin may act on the gonadal axis via the 
serotoninergic pathway and that Anton-Tay (1974) explained the modifications in brain serotonin levels, observed after melatonin administration (Anton-Tay et al., 1968), by a competitive action of melatonin on serotonin receptors resulting in an increased serotonin reuptake.

Considering other receptors it should be noted that Richardson et al. (1981) have shown that low concentrations of melatonin $\left(10^{-8}-10^{-5} \mathrm{M}\right.$, but not higher or lower doses) induce a release of somatostatin from rat hypothalamus in vitro. Melatonin is also known to decrease the number of estradiol receptors (Roy and Wilson, 1981).

In view of the fact that melatonin and its major brain metabolite, N-acetyl-5methoxykynurenamine, interact with brain benzodiazepine (BZP) binding sites in vitro (Marangos et al., 1982), the interaction between melatonin and BZP receptors in the brain is also of interest.

Pinealectomy, for example, results in a significant decrease of BZP receptors in cerebral cortex without significantly affecting their affinity (Lowenstein et al., 1985). More exactly, pinealectomy disrupts the diurnal rhythmicity of GABA and $B Z P$ binding in rat brain by increasing the sites number of GABA and decreasing that of BZP (Cardinali et al., 1986). A single s.c. injection of melatonin restores normal brain GABA and BZP binding in pinealectomized animals (Cardinali et al., 1986) that demonstrates a clear direct effect of the pineal hormone on these receptors.

Information on the possible direct role of melatonin on the activity of different receptor sites is still rare. All data reported, however, point to the importance of this type of action of melatonin.

\section{3. - Passive diffusion of melatonin : its possible action.}

The melatonin molecule is highly lipophilic rapidly crcssing all membranes. After systemic injection of radioactive melatonin (Anton-Tay and Wurtman, 1969 ; Vitte, 1987), the hormone enters the brain and many other structures.

Considering the control of seasonal function, we do not have clear evidence of of melatonin through other receptor sites is probable, it cannot be excluded that melatonin acts directly on several physiological functions by interfering with molecular processes. This approach to study the possible mechanism of action of melatonin has, indeed, been considered by most authors, but was often neglected in their experimental design.

A well known action of melatonin at the molecular level is its inhibitory effect on tubulin synthesis and on the assembly of microtubules in some hypothalamic cells (Winston et al., 1974 ; Cardinali and Freire, 1975). This property of melatonin could control a variety of processes. Microtubules indeed are intracytoplasmic organelles involved in many forms of movement including axonal transport and by consequence the secretory activity of given cells.

Experimentally, to demonstrate the existence of such an action of melatonin is difficult and very few data are presently available. Symons et al. (1985) observed that dispersed pituitary cells show a rapid $\mathrm{LH}$ response when LHRH is 
applied. This response can be inhibited by simultaneous administration of physiological amounts of melatonin. Abou-Samra et al. (1985), reported that in an in vitro system simultaneous administration of melatonin and corticotropin releasing factor (CRF) significantly increased the effect of CRF on beta-endorphin release from pituitary cells. In both experiments melatonin, which has no effect itself on the system studied - secretion of LH or of beta-endorphin - either inhibits or potentiates the effect of $\mathrm{LHRH}$ and $\mathrm{CRF}$, respectively. Because it is presently well-established (see above) that the duration of the elevated peak of melatonin concentration in the general circulation is directly related to the dark period, such experiments are of great interest for understanding the way in which the melatonin might act on physiological processes.

\section{4. - Steroid-mediated action of melatonin.}

As already noted besides its control of the annual sexual cycle, the pineal is known to be implicated in the timing of numerous other seasonal functions. In biological terms, however, reproduction appears to be one of the most important season-bound function since many of the others, e.g. the annual body weight cycle, pelage color changes, hibernation etc., are closely related to reproduction. It can therefore be assumed that some effects of the pineal are not direct but indirect effects consecutive to pineal-induced changes at the level of sexual hormones. The possible role of gonadal steroids in an indirect pineal control of some seasonal functions should especially be considered since such steroids can cross the blood-brain barrier to bind specifically to some brain structures which influence centrally controlled functions. In such a system the primary role of the pineal would be to synchronize seasonal changes in the reproductive axis with the seasons, the orchestration of other seasonally adaptative responses (hibernation, changes in body weight, etc.) resulting secondarily from changes in gonadal hormone concentration.

Very few studies deal with this problem. Some results obtained in the European hamster, considering two seasonal functions only (the annual cycles of reproduction and of hibernation) are of interest in this respect. This species presents a clear annual sexual cycle which, like in other temperate seasonal breeders, is photoperiodically regulated via a pineal mediated process (MassonPévet et al., 1987). The hibernation cycle of these animals is in phase relationship with that of reproduction while hibernation depends on the level of circulating testosterone (Canguilhem et al., 1987; Pévet et al., 1987). Changes in the circulating testosterone level also modify the central vasopressinergic innervation, especially at the level of the lateral septum (Buijs et al., 1986) a structure in which the AVP present is known to act centrally on temperature regulation (Cooper et al., 1979). From these observations the environmental and endocrine regulation of the reproductive and hibernation cycles of this animal can be summarized as follows (for details see Pévet et al., 1987).

1) The annual sexual cycle is synchronized with the seasons, especially by the annual changes in photoperiod. The pineal gland is indispensable for the 
integration of the photoperiodic message. Testicular regression is elicited by exposure to short daylight; 2) the reduction of testicular hormone levels subsequent to short days induces within some months changes in the central AVP innervation in some brain areas, e.g. the lateral septum. When the ambient temperature decreases such changes allow a fall of body temperature below normal levels ; 3) after several months of hibernation the testes begin to increase in size (endogenous recrudescence) while the increased testicular function might serve as a stimulus, via a progressive reestablishment of AVP innervation (e.g., in the lateral septum) to break off the period of hibernation.

Evidently this hypothesis needs further evaluation but it demonstrates that such an approach to study the mechanism of action of the pineal/melatonin should be considered.

\section{Conclusion.}

Although the importance of the pineal in the timing of the annual reproductive cycle and of other seasonal functions is well established, especially in hamster species, our present knowledge of the exact neuronal and neuroendocrine systems involved in such phenomena is still very poor.

It is clearly established that in the pineal the photoperiodic messages which reach the gland via a nervous pathway is transduced in a chemical message, the secretion of melatonin. Via the nocturnal peak of circulating melatonin the photoperiodic message is conveyed to the brain and probably also to some other organs. However, how melatonin acts at the cellular level and which are its sites of action is still to be discovered. Fragmentary data as exposed suggest that melatonin can act either through an action on melatonin receptors, on receptors of other transmitters, on several cellular processes after diffusion in cells or indirectly via, for example, central effects of gonadal steroids. Probably these different types of melatonin action co-exist, one of them being implicated in the regulation of a given function, the others regulating other functions. The closer investigation of such questions is a challenge for the next few years.

Colloquium on "Neuroendocrine mechanisms and light control of reproduction in domestic mammals " I.N.R.A., Nouzilly, 17-18 September 1987.

Acknowledgements. - The author wishes to thank Prof. J. Ariëns-Kappers for his stimulating interest in this study and for critically reading the manuscript and Miss F. Murro for secretarial aid.

This work was partly supported by INSERM $n^{\circ}$ CRE 876017.

Résumé. Rôle de la glande pinéale dans le contrôle photopériodique de la reproduction chez différentes espèces de hamster.

Chez les mammifères à activité sexuelle saisonnière le contrôle photopériodique de la reproduction implique la présence de la glande pinéale. Dans la présente revue, en nous basant sur les résultats expérimentaux obtenus chez 4 espèces de hamster (les hamsters 
dorés ou syriens, djungarians ou sibériens, turcs et européens), nous avons analysé 1) le rôle exact de cette glande dans ce phénomène, 2) le message transmis par cette glande et 3) le mécanisme d'action de ce message.

La mélatonine, l'un des 5-méthoxyindoles synthétisés de façon rythmique dans la glande pinéale, apparaît être l'hormone qui véhicule le message photopériodique. L'importance de la durée du pic nocturne de la mélatonine circulante est maintenant bien établie, mais nos connaissances sur les sites d'action et sur les mécanismes d'action de cette hormone sont encore limitées. Les données que nous possédons actuellement suggèrent que la mélatonine peut agir à différents niveaux: soit directement sur des récepteurs spécifiques, sur des récepteurs à d'autres transmetteurs, sur divers processus moléculaires après diffusion dans la cellule, ou soit indirectement par l'intermédiaire d'autres hormones tels que, par exemple, les stéroïdes gonadiques.

\section{References}

ABOU-SAMRA A. B., FEVRE-MONTANGE M., LORAS B., DURAND A., TOURNIAIRE J., BERTRAND J., 1985. Effect of indoleamines on beta-endorphin release by rat anterior pituitary cells. Neuroendocrinology, 41, 490-493.

ANTON-TAY F., 1974. Melatonin : effects on brain function. Adv. biochem. Psychopharmacol., 11, 315-324.

ANTON-TAY F., CHOU C., ANTON S., WURTMAN R. J., 1968. Brain serotonin concentration : elevation following intraperitoneal administration of melatonin. Science, 162, 277-278.

ANTON-TAY F., WURTMAN R. J., 1969. Regional uptake of ${ }^{3} \mathrm{H}$-melatonin from blood or cerebrospinal fluid by rat brain. Nature, 221, 474.

ARENDT J., 1986. Role of the pineal gland on melatonin in seasonal reproductive function in mammals. In J. R. CLARKE, Oxford review of reproduction biology Vol. 8, pp. 266-320. Clarendon Press, Oxford.

BAKER J. R., RANSON R. M., 1932. Factors affecting the breeding of the field mouse (Microtus agrestis). I. Light. Proc. R. Soc. B., 110, 313.

BECK O., PEVET P., 1984. Analysis of melatonin, 5-methoxytryptophol and 5-methoxyindoleacetic acid in the pineal gland and retina of hamster by capillary column gas chromatography mass spectrometry. J. Chromatogr. biomed. Appl., 311, 1-8.

BISSONETTE T. H., 1932. Modification of mammalian sexual cycles. Reactions of ferrets of both sexes to electric light added after dark in November and December. Proc. R. Soc. B., 110, 322.

BUIJS R. M., PEVET P., MASSON-PEVET M., POOL C. W., DE VRIES G. J., CANGUILHEM B., VIVIEN-ROELS B., 1986. Seasonal variation in vasopressin innervation in the brain of the European hamster (Cricetus cricetus). Brain Res., 37, 193-196.

CANGUILHEM B., VAULTIER J. P., PEVET P., CAUMAROS G., MASSON-PEVET M., BENTZ I., 1988. Photoperiodic regulation of body mass, food intake, hibernation and reproduction in intact and castrated male European hamster. (Submitted for publication).

CANGUILHEM B., VIVIEN-ROELS B., DEMEINEX B., MIRO J. L., MASSON-PEVET M., PEVET P., 1986. Seasonal and endogenous variations of plasma testosterone (T), thyroxine (T4) and triodothyronine (T3) in the European hamster. In I. ASSENMACHER and J. BOISSIN, Endocrine regulations as adaptative mechanisms to the environment $"$ pp. 291-296. Edition du CNRS, Paris.

CARDINALI D. P., FREIRE F., 1975. Melatonin effects on brain. Interaction with microtubule protein, inhibition of fast axoplasmic flow and induction of crystaloid and tubular formations in the hypothalamus. Mol. cell. Endocrinol., 2, 317-330.

CARDINALI D. P., LOWENSTEIN P. R., ROSENSTEIN R. E., GONZALES-SOLVEYRA C., KELLERSARMIENTO M. I., ROMEO H. E., ACUNA-CASTROVIEJO D., 1986 . Functional links between benzodiazepine and GABA receptors and pineal activity. In G. RACAGNI and A. $O$. DONOSO, GABA and endocrine function, pp. 155-163. Raven Press, New York. 
CARDINALI D. P., VACAS M. I., BOYER E. E., 1979. Specific binding of melatonin in bovine brain. Endocrinology, 105, 437-441.

CARTER D. S., GOLDMAN B. D., 1983a. Antigonadal effects of timed melatonin infusion in pinealectomized male Djungarian hamsters (Phodopus sungorus sungorus): Duration is the critical parameter. Endocrinology, 113, 1261-1267.

CARTER D. S., GOLDMAN B. D., 1983b. Progonadal role of the pineal in the Djungarian hamster (Phodopus sungorus sungorus). Mediation by melatonin. Endocrinology, 113, 1268-1273.

CARTER D. S., HALL V. D., TAMARKIN L., GOLDMAN B. C., 1982. Pineal is required for testicular maintenance in the Turkish hamster (Mesocricetus brandti). Endocrinology, 111, 863871.

COHEN M., ROSELLE D., CHABNER B., SCHMIDT I. J., LIPPMAN M., 1978. Evidence for a cytoplasmic melatonin receptor. Nature, 274, 894.

COOPER K. E., KASTING N. W., LEDERIS K., VEALE W. L., 1979. Evidence supporting a role for endogenous vasopressin in natural suppression of fever in the sheep. J. Physiol., 295, 33-45.

CZYBA J. C., GIROD G., DURAND N., 1964. Sur l'antagonisme epiphyso-hypophysaire et les variations saisonnières de la spermatogenèse chez le hamster doré (Mesocricetus auratus). $C . R$. Soc. Biol., 158, 742-745.

DUBOCOVICH M. L., 1983. Melatonin is a potent modulator of dopamine release in the retina. Nature, 306, 782-783.

DUBOCOVICH M. L., 1985. Characterization of a retinal melatonin receptor. J. Pharmacol. exp. Ther., 234, 395-401.

ELLIOT J. A., 1976. Circadian rhythms and photoperiodic time measurement in mammals. Fed. Proc., 35, 2339-2346.

GALZIN A. M., EON M. T., ESNAUD H., LEE C. R., PEVET P., LANGER S. Z., 1988. Day-night rhythm of 5-methoxytryptamine biosynthesis in the pineal giand of the golden hamster (Mesocricetus auratus). Submitted for publication.

GALZIN A. M., LANGER S. Z., 1986. Potentiation by deprenyl of the autoreceptor mediated inhibition of ${ }^{3} \mathrm{H}$-5-hydroxytryptamine release by 5 -methoxytryptamine. Naunyn-Schmiedeberg's Arch Pharmacol., 333, 330-333.

GOLDMAN B. D., 1983. The physiology of melatonin in mammals. In R. J. REITER. Pineal research reviews Vol. 1, pp. 145-181. A. R. LISS, New York.

HOFFMANN K., 1973. The influence of photoperiod and melatonin on testes size. body weight and pelage colour in the Djungarian hamster. J. comp. Physiol., 85, 267-282.

HOFFMANN K., 1979. Photoperiod, pineal, melatonin and reproduction in hamster. In J. ARIËNSKAPPERS and P. PEVET, The pineal gland of vertebrates including man. Vol. 52, pp. 397-415. Elsevier, North Holland Biomedical Press, Amsterdam, Progress in Brain Research.

HOFFMANN K., 1981a. Photoperiodic function of the mammalian pineal organ. In A. OKSCHE and P. PEVET, The pineal gland: photobiology, biochronometry, endocrinology, pp. 123-138. Elsevier North Holland, Biomedical Press, Amsterdam.

HOFFMANN K., 1981b. Photoperiodism in vertebrates. In Biological rhythms, pp. 449-473. Ed. J. Aschoff. Plenum Press, New York.

HOFFMANN K., 1982. The critical photoperiod in the Djungarian hamster, Phodopus sungorus. In J. ASCHOFF, S. DAAN and G. GROOS, Vertebrate circadian system, pp. 297-304. Springer Verlag, Berlin.

HOFFMANN K., 1985. Interaction between photoperiod, pineal and seasonal adaptation in mammals. In B. MESS, Cs. RUZSAS, L. TIMA and P. PEVET, The pineal gland : current state of pineal research, pp. 211-230. Akademia Kiado, Budapest, Elsevier, Amsterdam 1985.

HOFFMANN R. A., REITER R. J., 1965. Pineal gland. Influence on gonads of male hamster. Science, 148, 1609-1611.

HONG S. M., ROLLAG M. D., STETSON M. M., 1986. Maintenance of testicular function in turkish hamsters : interaction of photoperiod and the pineal gland. Biol. Reprod., 34, 527-531.

KANO T., MIYACHI Y., 1976. Direct action of melatonin on testosterone and cyclic GMP production using rat testis in vitro. Biochem. biophys. Res. Commun., 72, 969-975. 
LANG U., AUBERT M. L., SIZONENKO P. C., 1981. Location of melatonin receptors. Pediatr. Res., 15, 80 (Abstr.).

LAUDON M., ZISAPEL N., 1985. Characterization of central melatonin receptors using ${ }^{125} /$-melatonin. FEBS Lett., 197, 9-12.

LAUDON M., ZISAPEL N., 1987. Impact of circulating oestradiol on melatonin binding sites in discrete areas of the female rat brain. Brain Res., 402, 146-150.

LI K., REITER R. J., VAUGHAN M. K., OAKNIN S., TROIANI M. E., ESQUIFINO A. I., 1987. vated ambient temperature retards the atrophic response of the neuroendocrine-reproductive axis of male Syrian hamster to either daily afternoon melatonin injections or to short photoperiod. Neuroendocrinology, 45, 356-362.

LOWENSTEIN P. R., ROSENSTEIN R., CARDINALI D. P., 1985. Melatonin reverses pinealectomyinduced decrease of benzodiazepine binding in rat cerebral cortex. Neurochem. Int., 7, 675681.

MARANGOS P. J., PATEL J., BOULENGE J. P., CLARK-ROSENBERG R., 1982. Characterization of peripheral type benzodiazepine binding site in brain using ${ }^{3} \mathrm{H}-\mathrm{RO}$ 5-4864. Molec. Pharmacol., 22, 26-32.

MASSON-PEVET M., PEVET P., VIVIEN-ROELS B., 1987. Pinealectomy and constant release of melatonin or 5-methoxytryptamine induce atrophy in the European hamster. J. Pineal Res., 4, 79-88.

MEFFORD I. N., CHANG P., KLEIN D. C., NAMBOODIRI M. A. A., SUGDEN D., BARCHAS J., 1983. Reciprocal day/night relationship between serotonin oxidation and $\mathrm{N}$-acetylation products in the rat pineal gland. Endocrinology, 113, 1582-1586.

MURPHY M. R., 1985. History of the capture and domestication of the syrian golden hamster (Mesocricetus auratus Waterhouse). In H. I. SIEGEL, The hamster: reproduction and behavior, pp. 3-20. Plenum Press, New York.

NILES L. P., $1987 .{ }^{3} \mathrm{H}$-melatonin binding in membrane and cytosol fractions from rat and calf brain. J. Pineal Res., 4, 89-98.

PANKE E. S., ROLLAG M. D., REITER R. J., 1980. Effects of photoperiod on hamster pineal melatonin concentrations. Comp. Biochem. physiol., 66A, 691-693.

PETTERBORG L. J., RICHARDSON B. A., REITER R. J., 1981. Effect of long or short photoperiod on pineal melatonin content in the white-footed mouse, Peromyscus leucopus. Life Sci., 29. $1623-1627$.

PEVET P., 1983. Is 5-methoxytryptamine a pineal hormone ? Psychoneuroendocrinology, 8, 61-73.

PEVET P., BUIJS R. M., MASSON-PEVET M., CANGUILHEM B., 1987. Pineal and photoperiodic control of different seasonal functions in the European hamster : importance of gonadal steroids and of the central vasopressinergic innervation. In G. P. TRENTINI, G. De GAETANI and P. PEVET, Fondamentals and clinics in pineal research. Raven Press, New York (in press).

PEVET P., MASSON-PEVET M., VIVIEN-ROELS B., 1986a. Photoperiod, temperature, melatonin, 5-methoxytryptamine and seasonal reproduction : some data on the golden hamster. In $\mathrm{R}$. J. REITER and M. KARASEK, Advances in pineal research, vol. 1, pp. 185-195. John Libbey, London.

PEVET P., VIVIEN-ROELS B., BONN D., 1986b. Effect of temperature on the gonadal atrophy induced by short photoperiod in the golden hamster. In I. ASSENMACHER and J. BOISSIN, Endocrine regulations as adaptative mechanisms to the environment, pp. 201-206. Edition du CNRS, Paris.

QUAY W. B., 1963. Effect of dietary phenylalanine and tryptophan on pineal and hypothalamic serotonin levels. Proc. Soc. exp. Biol. Med., 114, 718-721.

REITER R. J., 1969. Pineal gonadal relationships in male rodents. In C. GUAL, Progress in Endocrinology, pp. 631-636. Excepta medica, Amsterdam.

REITER R. J., 1973. Pineal control of seasonal reproductive rhythm in male golden hamsters exposed to natural daylight and temperature. Endocrinology, 92, 423-430.

REITER R. J., 1975. The pineal gland and seasonal reproductive adjustments. Int. J. Biometeorol., 19. 282-288.

REITER R. J., 1980. The pineal and its hormones in the control of reproduction in mammals. Endocr. Rev., 1, 109-131. 
REITER R. J., 1983. The role of light and age in determining melatonin production in the pineal. In J. AXELROD, F. FRASCHINI and G. P. VELO, The pineal and its endocrine role, pp. 227241. Plenum Press, N. Y.

REITER R. J., 1987a. Photoperiod, pineal and reproduction in mammals including man. In P. PEVET, Comparative physiology of environmental adaptations, part 3. Adaptation to climatic changes, pp. 71-81. Karger, Basel.

REITER R. J., 1987b. The melatonin message : Duration versus coincidence hypothesis. Life Sci, 40. $2119-2131$.

REITER R. J., VAUGHAN M. K., WARING P. J., 1977. Prevention by melatonin of short day induced atrophy of the reproductive systems of male and female hamsters. Acta endocrinol., 84, 410-418.

RICHARDSON S. B., HOLLANDER C. S., PRASAD J. A., HIROOKA T., 1981. Somatostatin release from rat hypothaiamus in vitro : effects of melatonin and serotonin. Endocrinology, 109, 602-612.

ROBERTS A. C., MARTENSZ N. D., hASTINGS M. H., HERBERT J., 1985. Changes in photoperiod alter the daily rhythms of pineal melatonin content and hypothalamic beta-endorphin content and the LH response to naloxone in the male Syrian hamster. Endocrinology, 117, $141-147$.

ROLLAG M. D., PANKE E. S., REITER R. J., 1980. Pineal melatonin content in male hamsters throughout the seasonal reproductive cycle. Proc. Soc. exp. Biol. Med., 165, 330-334.

ROY E. J., WILSON M. A., 1981. Diurnal rhythm of cytoplasmic estrogen receptors in the rat brain in the absence of circulating estrogens. Science, 213, 1523-1526.

SKENE D. J., PEVET P., VIVIEN-ROELS B., MASSON-PEVET M., ARENDT J., 1987. Effect of different photoperiods on concentrations of 5-methoxytryptophol and melatonin in the pineal gland of the syrian hamster. J. Endocrinol., 114, 301-309.

SMITH A. R., KAPPERS J. A., 1975. Effect of pinealectomy, gonadectomy, pCPA and pineal extracts on the rat parvocellular neurosecretory hypothalamic system: a fluorescence histochemical investigation. Brain Res., 86, 353-371.

STEINLECHNER S., STEGER R. W., KING T. S., REITER R. J., 1983. Diurnal variation in the serotonin content and turnover in the pineal gland of the syrian hamster. Neurosci. Lett., 35, 167-172.

STETSON M. H., WATSON-WHITMYRE M., 1984. Physiology of the pineal gland and its hormone melatonin in annual reproduction in rodents. In R. J. REITER, The pineal gland, pp. 109-153. Raven Press, New York.

STETSON M. H., WATSON-WHITHMYRE M., 1986. Effects of exogenous and endogenous melatonin on gonadal function in hamsters. $J$. neural Transm., suppl. 21, 55-80.

SYMONS A. M., ARENDT J., PRYDE S. J., 1985. Differential effects of melatonin on the stimulated release of luteinizing hormone from dispersed pituitary cells of the prepubertal female rat. J. Endocrinol., 107, 107-112.

TAMARKIN L., REPPERT S. M., KLEIN D. C., PRATT B., GOLDMAN B. D., 1980 . Studies on the daily pattern of pineal melatonin in the syrian hamster. Endocrinology, 107, 1525-1529.

VANECEK J., PAVLIK A., ILLNEROVA H., 1987. Autoradiographic localization of ${ }^{125}$ I-melatonin binding in the rat hypothalamus : suprachiasmatic nuclei and median eminence. EPSGNewsletter, suppl. 7, p. 143 (Abstr.).

VITTE P. A., 1987. Les effets centraux de la mélatonine. Thèse Doct., Univ. de Lyon.

WEATHERHEAD B., LOGAN A., 1981. Interaction of alpha-melanocyte-stimulating hormone, melatonin, cyclic-AMP and cyclic-GMP in the control of melanogenesis in hair follicle melanocytes in vitro. J. Endocrinol., 90, 89-96.

WINSTON M., JOHNSON E., KELLERHER J. K., BANERJEE S., MARGULIS L., 1974. Melatonin : cellular effects on live stentors correlated with the inhibition of colchicine-binding to microtubule protein. Cytobios., 9, 237-243.

ZISAPEL N., LAUDON M., 1982. Dopamine release induced by electrical field stimulation of rat hypothalamus in vitro: inhibition by melatonin. Biochem. Biophys. Res. Commun., 104, 1610-1611.

ZISAPEL N. LAUDON M., 1987. A novel melatonin antagonist affects melatonin-mediated processes in vitro and in vivo. Europ. J. Pharmacol., 136, 259-260. 